ppi $201502 Z U 4645$

Esta publicación científica en formato digital es continuidad de la revista impresa ISSN-Versión Impresa 0798-1406 / ISSN-Versión on line 2542-3185Depósito legal pp $197402 Z$ U34
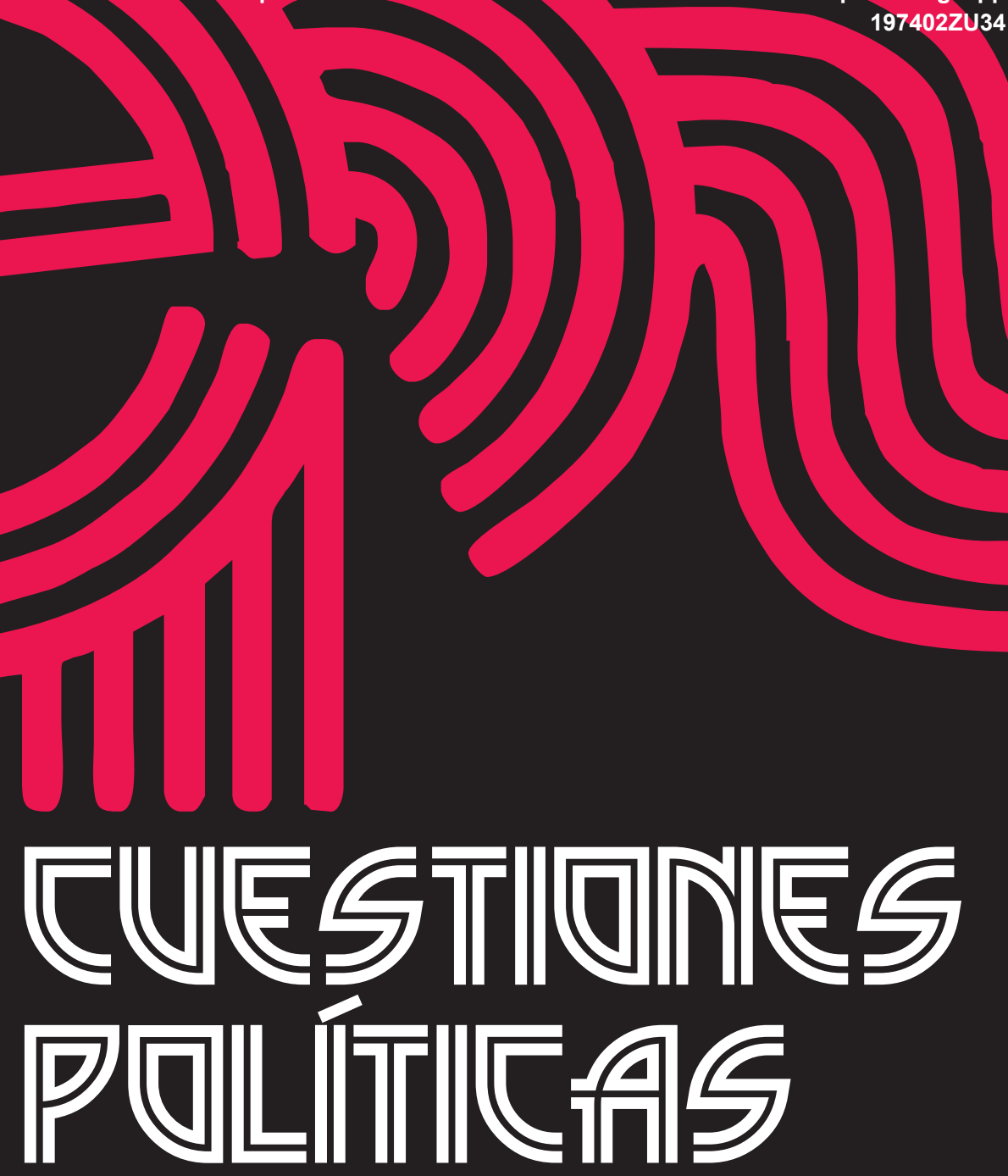

Instituto de Estudios Políticos y Derecho Público "Dr. Humberto J. La Roche" de la Facultad de Ciencias Jurídicas y Políticas de la Universidad del Zulia Maracaibo, Venezuela
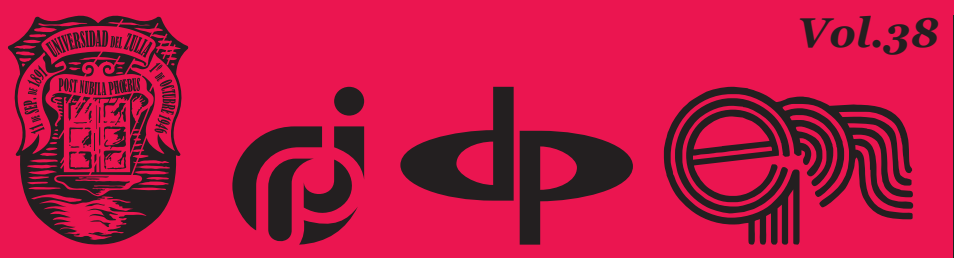

$N^{\circ}$ Especial 2da Parte 2020 


\title{
Restriction of the Rights of Russian Senators as a Political Responsibility
}

\author{
DOI: https://doi.org/10.46398/cuestpol.382e.21
}

\author{
Ruslan Faritovich Garipov * \\ Denis Ivanovich Igonin **
}

\begin{abstract}
This article explores the features of the implementation of individual parliamentary rights by members of the Federation Council, the upper house of the Russian legislative assembly. The relevance of the study is since in recent years there has been a transformation in informal practices of political influence on parliamentarians. In this sense, the object of the study was the analysis of individual legal norms, the regulations of the Federation Council and the practice of holding parliamentary hearings. The authors focused on the negative consequences expressing the responsibility of senators, considering the ambiguous statutory regulation of such measures in modern Russian politics. During the development of the scope of activities carried out by the upper house of the Federal Assembly, the reasons by which its members could lose their powers were significantly expanded. By way of conclusion, it was noted that, despite the rarity of the application of such sanctions, the authors recorded a systematization of forms and measures of responsibility used for political purposes. Such tendencies create artificial barriers to the implementation of certain senatorial powers and acquire a political character.
\end{abstract}

Keywords: Political responsibility; parliamentarism; council of the Russian federation; Federal Assembly; senator status.

Associate Professor (Department of Political Science) Institute of Sociology, Philosophy and Mass Communications, Kazan Federal University. ORCID ID: https://orcid.org/oooo-0002-6401-7675. Email: ruslanweb@bk.ru

** Associate Professor (Department of Political Science) Institute of Sociology, Philosophy and Mass Communications, Kazan Federal University. ORCID ID: https://orcid.org/oooo-0002-8316-6916. Email: IgoninDenis1983@yandex.ru 


\section{Restriction of the Rights of Russian Senators as a Political Responsibility \\ La restricción de los derechos de los senadores rusos como responsabilidad política}

\section{Resumen}

Este artículo explora las características de la implementación de los derechos parlamentarios individuales por parte de los miembros del Consejo de la Federación, la cámara alta de la asamblea legislativa rusa. La relevancia del estudio se debe a que en los últimos años se ha producido una transformación de las prácticas informales de influencia política sobre los parlamentarios. En este sentido, el objeto del estudio fue el análisis de las normas legales individuales, el reglamento del Consejo de la Federación y la práctica de realizar audiencias parlamentarias. Los autores se centraron en las consecuencias negativas que expresan la responsabilidad de los senadores, teniendo en cuenta la ambigua regulación estatutaria de tales medidas en la política rusa moderna. Durante el desarrollo del alcance de las actividades realizadas por la cámara alta de la Asamblea Federal, se ampliaron significativamente los motivos en virtud de los cuales sus miembros podrían perder sus poderes. A modo de conclusión se notó que, a pesar de la rareza de la aplicación de tales sanciones, los autores registraron una sistematización de formas y medidas de responsabilidad utilizadas con fines políticos. Tales tendencias crean barreras artificiales para la implementación de ciertos poderes senatoriales y adquieren un carácter político.

Palabras clave: responsabilidad Política; parlamentarismo; consejo de la federación rusa; Asamblea Federal; condición de senador.

\section{Introduction}

As a rule, the responsibility of the senators of the Federation Council is legal. It is defined in the Constitution of the Russian Federation and is specified in special legislation. Therefore, parliamentarians of the upper house of the Federal Assembly have immunity. Federal Law of 1994 No. 3-FZ (Federal Law of No. 3-FZ, 1994) requires the use of a special procedure if a senator is brought to administrative or criminal responsibility. In addition, senators are endowed with indemnity, exempting them from responsibility for statements and opinions. However, this indemnity does not apply to libel, public insults, and other violations committed by parliamentarians. In any of these cases, a senator is deprived of parliamentary immunity. 
In some cases, those sanctions that are prescribed to members of the Federation Council in Russian law are exclusively political in nature. Thus, the basis for the application of these measures is not only a violation of legal, but also political norms.

\section{Methods}

The methodological basis of the study conducted is represented by a system-functional approach to the analysis of organizational issues devoted to the implementation of the rights of Russian senators. As a result, it became possible to establish several directions in understanding political responsibility, which manifests itself in the limitation of senatorial powers.

The formal legal approach to the essence of political responsibility prevailed for several decades (Knysh, 2017). However, to date, the responsibility of senators takes on a broader meaning. In particular, it can be expressed in a wide variety of negative consequences imposed on the conditionally "guilty" parliamentarian (Novikova, 2017; Krysanov, 2014).

In case of violation of political norms by a senator, special relations arise; they are aimed at bringing him to the responsibility complicated by the power component (Tsutiev and Tlyabichev, 2016). Therefore, in modern science, criteria that distinguish political responsibility from other methods of negative impact on parliamentarians are formed (Musienko, 2007; Sherov, 2013).

In accordance with the first approach, political responsibility should be understood as the constitutionally established measures of influence in relation to the subjects of power (Brady, 1999). Hence, the identification of the constitutional legal responsibility of senators with their political responsibility is developed among researchers. Therefore, the imposition on parliamentarians of sanctions regulated by constitutional law is considered a political responsibility.

According to the second approach, political responsibility is a combination of administrative and disciplinary measures imposed on a subject of power (Peacock, 2004). Their application is permissible only at the official state level and is open in nature. Because of this, if the senator is deprived of his/her powers or if they are significantly limited, he or her is punished for unlawful behaviour. In particular, the prohibition of a senator to speak during a parliamentary meeting is, according to individual authors, a case of political responsibility (Berlyavsky and Taraban, 2012).

If we follow the third approach, then political responsibility is a comprehensive institution that combines various measures of negative 
impact on the senator in order to achieve certain behaviour from him/her (May, 1989; Dunn, 1992).

In this form, it is permissible for the senator to apply the legal sanctions, including disciplinary and financial ones, with a combination of illegal instruments (Tsakatika, 2004) (for example, refusal to provide information, ignoring the senatorial request, refusal in personal appointment of the senator by officials, etc.).

\section{Results and Discussion}

Political and legal literature is dominated by the notion that bringing a government representative to any type of responsibility can affect his/her political activity (Schiff, 2017). In addition, such an impact can significantly hamper a senatorial career. Thus, both the deprivation of senatorial powers and the restriction on senatorial rights express the essence of political responsibility. This is confirmed by examples from Russian political practice.

Today, ignoring senatorial requests, refusals to provide information or speaking at sites owned by the media are common. Significantly less often, senators lose their parliamentary mandates, except of their own free will.

A similar practice (the non-recognition of the authority of parliamentary representatives) is a long-standing Russian tradition. For example, in 2016 there was a confrontation between the new composition of the Legislative Assembly of the Nizhny Novgorod Region and the regional Government. The subject of political debate was the election of the Chairman of the Nizhny Novgorod Regional Parliament. Not only Plenipotentiary of the President of Russia in the Volga Federal District M. Babich had to intervene into this conflict, but also several senators representing the Nizhny Novgorod Region in the Federation Council. As a result, individual executive bodies of the federal and regional levels began to ignore the requests of senators involved in the conflict. The rights to appeal and to receipt members of the Federation Council by regional officials were also limited. Against the background of these and some other factors, the candidate who was supported by the governor of the region became the chairman of the Nizhny Novgorod regional parliament.

The current Russian legislation provides only two negative measures:

1) Depriving a senator of the opportunity to speak at a meeting held in the Federation Council.

2) Early termination of senatorial powers. 
Despite the regulation of these sanctions by legal norms, individual conditions for their use remain at the discretion of senior officials of the Federation Council.

So, Art. 9 of Federal Law 1994 No. 3-FZ makes a reference to the Regulations of the Upper House of the Federal Assembly (Resolution of the Federation Council of the Federal Assembly of the Russian Federation No. 33-SF, 2002) to establish responsibility for violation of ethical standards by senators. In most cases, a member of the Federation Council is deprived of the right to speak. Such a measure is imposed in two versions: without warning and with the prior approval of other senators. However, the prevailing cases are unilateral decisions of the chairman to implement such a sanction.

A ban on public speaking is imposed if:

- There is no prior permission for a public speech at a meeting from the side of the chairman (clause 2, article 53 of the Federation Council Regulations).

- When using rude and insulting expressions, causing damage to the honour and dignity of citizens and officials.

- In calls for illegal actions.

- When trying to use knowingly false information.

- With unsubstantiated accusations.

- When inciting national and social discord (paragraph 3 of article 53).

For example, in 2018, the speaker of the Federation Council Valentina Matvienko interrupted the speech of Senator Lyudmila Narusova in connection with her opinion on the scandal involving the Minister of Culture Vladimir Medinsky. Despite the information received from several sources regarding plagiarism in the thesis of the Minister, the Chairperson regarded the speech of Narusova as an unsubstantiated accusation. Moreover, Art. 53 of the Federation Council Regulations does not disclose what exactly should be understood by this category.

Similarly, the phrase "abuse of the right to participate in the discussion" was not disclosed at the legal level. A senator is deprived of speech for this reason, but the procedure for imposing such a sanction is more democratic. In particular, the issue of abuse should be put to the vote of members of the Federation Council, thereby only they have the right to prohibit a particular senator from speaking at this meeting.

At the same time, examples from parliamentary practice demonstrate the preservation of the chairman's prerogative to detect abuse. So, on October 9, 2019 Valentina Matvienko interrupted the speech of Senator 
N.I. Ryzhkov in connection with his criticism of the implementation of presidential decrees and the situation with forest fires in the country.

In accordance with the Regulations, a member of the Federation Council is not limited in touching upon various issues related to the agenda in one way or another. However, in fact, there is developed another (not legal, but political) norm, according to which it is impossible to ask questions to the executive branch within the framework of the so-called "Government hour". According to V. Matvienko, for the implementation of these intentions it is necessary to use other venues in order not to turn the meetings of the Federation Council into "self-PR" (Matvienko interrupted Narusova's speech due to statements about Medinsky, 2020).

In some cases, sanctions not mentioned in the current Russian legislation are observed. All of them are associated with the restriction of certain powers of senators.

For example, members of the Federation Council have the right to send their own requests to various bodies and organizations. However, there were cases when administrations of global media and social networks (Twitter, Apple, Google) ignored such appeals by Russian senators. At the same time, Art. 14 of the Federal Law dated 1994 No. 3-FZ designates only bodies and officials of the Russian authorities obliged to respond to relevant senatorial requests.

At the same time, the consequences of failure to comply with such a requirement on the part of the Government of the Russian Federation, the General Prosecutor's Office, and the Investigative Committee are not legally determined, since responsibility arises only for specific officials, and not for authorities.

\section{Summary}

While remaining the upper house of the Russian parliament, the Federation Council has formed a set of rules in the internal work regulations, for the violation of which there may be political sanctions. A smaller volume of such norms is legal requirements. Informal practices remain more efficient that make it possible to influence a particular senator for political purposes.

Unlike deputies of the State Duma of Russia, senators do not represent the interests of political parties. This reduces the number of guarantees for their parliamentary activities, providing the opportunity to punish members of the Federation Council only to two subjects: 
1) The management apparatus of the Federation Council.

2) The political elite of Russian regions, whose interests are represented by a senator in the upper house of parliament.

It seems that the political norms mediating parliamentary activity should be static. Their action is accompanied by a streamlined mechanism for applying measures aimed at maintaining the political order within the walls of the Federation Council. However, far from all of these regulations have been maintained for at least a decade in Russia. Depending on the position taken by the federal executive branch, the actual regulations for the work of senators are changing. If in a period they can actively criticize the bills proposed by the Government of Russia, in modern times such criticism is fraught with personal political consequences for members of the Federation Council.

\section{Conclusions}

The political responsibility of the members of the Federation Council can be selective in nature and often involves a breach of not only legal, but also political norms. As a rule, it is fragmented and applies only to individual senators who demonstrate opposition rhetoric to the executive branch of the Russian Federation power. Current legislation is called upon to eliminate such practice, in which it is necessary to disclose the definitions used and the grounds for imposing certain sanctions, as well as to limit the discretion of persons authorized to influence members of the Federation Council.

Sanctions expressing the political responsibility of Russian senators have not only a formal (legal), but also an informal (political) character. The first may include legal requirements formulated in laws in an unjustifiably broad sense. This allows changing the interpretation of some of the grounds for bringing members of the Federation Council to legal responsibility.

Informal measures of political influence on senators are not defined in the norms of laws but are practiced by individual actors of modern Russian politics. As a result of this, such measures may have a "shadow" character. The latter is expressed in the influence on the will of a member of the Federation Council to maintain a political course or deter criticism of the ruling party. As a result, today the restriction of the rights of senators takes the form of political responsibility contrary to the legitimate methods of political struggle at the federal level. 
Ruslan Faritovich Garipov y Denis Ivanovich Igonin

284 Restriction of the Rights of Russian Senators as a Political Responsibility

\section{Acknowledgements}

The work is performed according to the Russian Government Program of Competitive Growth of Kazan Federal University.

\section{Bibliographic References}

BERLYAVSKY, Leonid; TARABAN, Nikolay. 2012. "The recall of the deputy of the representative body: the ratio of political and constitutional responsibility" In: State power and local government. Vol. 7, pp. 30-33.

BRADY, Chris. 1999. "Collective responsibility of the Cabinet: an ethical, constitutional or managerial tool?” In: Parliamentary Affairs. Vol. 52, No. 2, p. 214.

DUNN, John. 1992. "Interpreting political responsibility, Essays, 1981-1989" In: Canadian Journal of Political Science. Vol. 25, pp. 192-193.

FEDERAL LAW OF No. 3-FZ.1994. "On the Status of a Member of the Federation Council and the Status of a Deputy of the State Duma of the Federal Assembly of the Russian Federation". (as amended on July 3, 2019). Collection of Legislation of the Russian Federation, 2, Art. 74, 1994; No. 27, Article 3532, 2019.

KNYSH, Villy. 2017. "Theoretic and legal aspects of interaction of constitutional and administrative responsibility" In: Sciences of Europe. Vol. 17-1, No. 17, pp. 65-69.

KRYSANOV, Alvin. 2014. "Some aspects of constitutional legal responsibility of deputies of the State Duma and the Federation Council of the Russian Federation" In: Problems of ensuring, implementing, protecting constitutional human rights and freedoms. No. 3, pp. 104-113.

MATVIENKO INTERRUPTED NARUSOVA'S SPEECH DUE TO STATEMENTS ABOUT MEDINSKY. 2020. Available online: https:// russian.rt.com/russia/news/494483-matvienko-narusova-sovfed. Consultation date: 26/05/2020.

MAY, Larry. 1989. "Philosophers and political responsibility" In: Social Research. Vol. 56, pp. 877-901.

MUSIENKO, Sandra. 2007. "Conceptualization of the concept of political responsibility” In: Management issues. Vol. 4, No. 25, pp. 221-224. 
NOVIKOVA, Victor. 2017. "On the issue of responsibility of members of the Federation Council and deputies of the State Duma of the Federal Assembly of the Russian Federation" In: Modern trends in the development of science and technology. Vol. 2-6, pp. 104-108.

PEACOCK, Mark. 2004. "On political competition: democracy, opinion and responsibility” In: Constitutional Political Economy. Vol. 15, No. 2, pp. 187-204.

RESOLUTION OF THE FEDERATION COUNCIL OF THE FEDERAL ASSEMBLY OF THE RUSSIAN FEDERATION No. 33-SF. 2002. "On the Regulations of the Federation Council of the Federal Assembly of the Russian Federation", (as amended on September 25, 2019). Collection of Legislation of the Russian Federation, 7, Art. 635, 2002; No. 40, Article 5497, 2019.

SCHIFF, Jade. 2017. "Political responsibility: Responding to predicaments of power" In: Contemporary Political Theory. Vol. 16, No. 4, pp. 561-565.

SHEROV, Shan. 2013. "Correlation of constitutional responsibility and political responsibility” In: Legal life. Vol. 2, No. 2, pp. 113-122.

TSAKATIKA, Myrto. 2004. Political responsibility and the European Union. Manchester University Press. Manchester, England

TSUTIEV, Alex; TLYABICHEV, Shoana. 2016. "Parliamentary discipline and parliamentary responsibility of deputies" In: New Science: Current Status and Development Paths. Vol. 12, No. 4, pp. 232-235. 

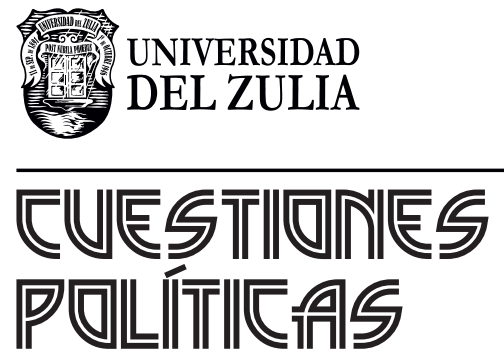

Vol.38 NEspecial

Esta revista fue editada en formato digital y publicada en diciembre de 2020, por el Fondo Editorial Serbiluz, Universidad del Zulia. Maracaibo-Venezuela 